\title{
Stratigraphy, tephrochronology, and
} structure of part of the Miocene Truckee Formation in the Trinity Range-Hot Springs Mountains area, Churchill County, west-central Nevada

By John H. Stewart ${ }^{1}$ and Michael E. Perkins ${ }^{2}$

Open File Report 99-330

1999

This report is preliminary and has not been reviewed for conformity with U.S. Geological Survey editorial standards or with the North American Stratigraphic Code. Any use of trade, product or firm names is for descriptive purposes only and does not imply endorsement by the U.S. Government.

\section{U.S. DEPARTMENT OF INTERIOR}

U.S. GEOLOGICAL SURVEY

1 U.S. Geological Survey, 345 Middlefield Rd., Menlo Park CA, 94025

2 Department of Geology and Geophysics, University of Utah, 717 W.C. Browning Building, Salt Lake City, Utah, 84112 


\section{CONTENTS}

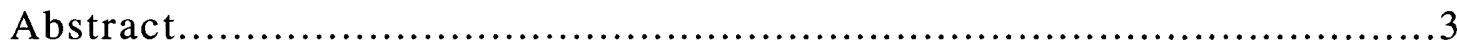

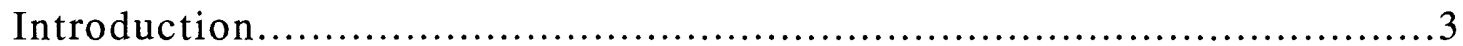

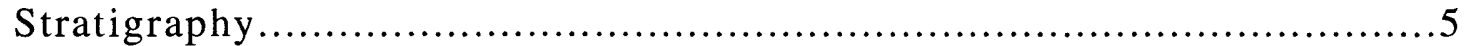

Truckee Formation...................................................... 5

Lower member................................................. 5

Middle member................................................ 5

Upper member............................................. 5

Upper member of Truckee Formation east of Hill-4561 fault....7

Upper member of Truckee Formation west of Hill-4561 fault...7

Conglomerate and gravel unit........................................... 10

Tephrochronology ........................................................ 10

Environments of deposition........................................................ 16

Onset of basin and of Basin and Range faulting.................................... 16

Left-lateral Hill-4561 fault...................................................... 18

References cited............................................................... 18

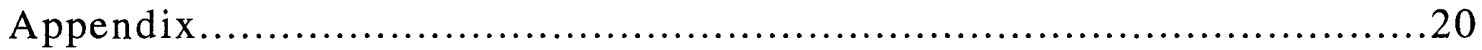

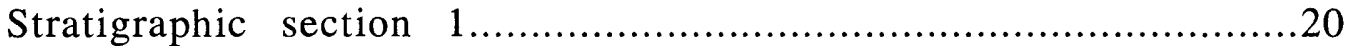

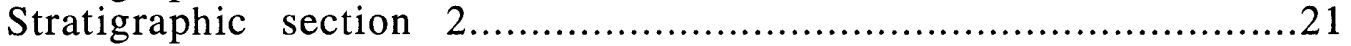

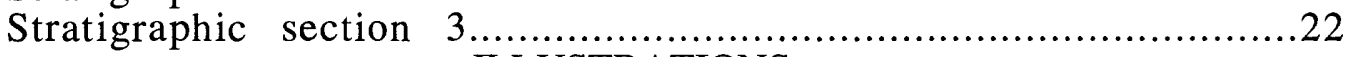

Figure $\quad$ 1. Index map of Nevada showing location of

Trinity Range-Hot Spring Mountains area.........................4

2. Geologic map of Trinity Range-Hot Spring Mountains area.

Mapping east of Interstate 80 from Benoit and

others (1982)

In pocket

3. Stratigraphic columns of upper member of the

Truckee Formation.........................................6

4. Photographs of tufa in unit Ttucg and Ttut........................... 8

5. Photographs of details of tufa....................................... 9

6. Photograph of Hill 4561 showing drag fold and left-lateral fault.

Dark colored outcrops on left-hand side of photographs are

breccias and intrusive of basalt.....................................14

7. Diagram showing correlation of ash-fall tuffs in Hill-4561 area.......15

8. Diagram showing correlation and dates of vitric tuffs in Truckee

Formation in the Trinity Range-Hot Springs Mountains area with vitric tuffs in correlative strata in three other areas of west-

central Nevada.

\section{TABLES}

Table 1. Stratigraphic location and correlation of tephra samples

Table 2. Electron probe microanalyses of glass shards - average composition...............13

Table 3. XRF analyses of glass shard separates. 


\section{ABSTRACT}

The Miocene Truckee Formation is relatively well exposed in an area along the southwest flank of the Trinity Range and the northwest flank of the Hot Springs Mountains, Churchill County, western Nevada. This report describes the previously little studied part of these exposures, in particular the upper member of the Truckee Formation which is at least $464 \mathrm{~m}$ thick and consists of a variety of rock types including diatomaceous siltstone, sandstone, conglomerate, volcanic breccia, limestone, and tufa. The upper part of the Truckee Formation shows an important transition from quiet-water, fine-grained lacustrine deposits in the lower part to interstratified lacustrine, coarse-grained alluvial-fan deposits, and megabreccia deposits in the upper part of the section. This transition is accompanied by a change in clasts composition from mostly clasts of Tertiary volcanic rocks in the lower part of the section, to mixed clasts of Tertiary volcanic rocks and Mesozoic rocks in the middle and upper parts of the section. Sands derived from a granitic provenance are present in conglomerate and gravel deposits overlying the Truckee Formation. This progression of clast types indicates an unroofing of the source terrane. These upward changes in coarseness and composition of the strata mark the onset of nearby Basin and Range block faulting that led to development of present-day topography. Tephrochronology studies indicate that the middle and upper members of the Truckee Formation range in age from $11.8 \mathrm{Ma}$ to $9.8 \mathrm{Ma}$ and that the onset of coarse-grained deposits and of Basin and Range structure started about 11 m.y. ago.

A major north-south-striking fault, here referred to as the Hill-4561 fault, cuts across the study area. Marked changes in sedimentary facies across the fault suggest lateral movement, which is left lateral based on a form of a drag fold.

\section{INTRODUCTION}

This report describes exposures (Fig. 1,2) of the Miocene Truckee Formation along the southwest flank of the Trinity Range and the northwest flank of the Hot Spring Mountains, about $8 \mathrm{~km}$ north northeast of Bradys Hot Springs in Churchill County, Nevada, and about $70 \mathrm{~km}$ northeast of Reno, Nevada. Interstate Highway 80 crosses the eastern part of the area. King (1878), during his study of the Geology of the Fortieth Parallel (1876), described and named the Truckee Formation for exposures in the eastern part of the area. Subsequently, Axelrod (1956) studied the stratigraphy and flora of the Hot Spring Mountains and vicinity, and described and named the Cloropagus Formation and the overlying Desert Peak Formation, that lies below the Truckee Formation. Axelrod (1956) mapped part of the area and reported extensively on Miocene flora in the Cloropagus Formation. Willden and Speed (1974) mapped and described the general geology of the region during their study of the geology of Churchill County. Krebs and others (1987), briefly describe diatoms from the extensive exposures of diatomite in the area. The geology and geothermal characteristics of the Desert Peak geothermal area were thoroughly studied by Benoit and others (1982). The Desert Peak geothermal area, including the area near Bradys Hot Springs, has been developed for geothermal power (Garside and Shilling, 1979; Benoit and others, 1982). One currently active, and several abandoned, diatomite mines are common in the middle member of the Truckee Formation (Willden and Speed, 1974). Companion studies have been made of Miocene strata in the Cobble Cuesta area, Gabbs Valley, $120 \mathrm{~km}$ southeast of the Trinity Range-Hot Springs Mountains area and in the Middlegate area, $110 \mathrm{~km}$ south southwest of the Trinity RangeHot Springs Mountains area (Stewart,1992; Stewart and others, 1999a,b).

The present study focuses on a relatively small part of the Desert Peak-Trinity Range area. It describes a previously little studied part of the Truckee Formation that shows an important change from quiet-water fine-grained lacustrine deposits to interstratified lacustrine, coarse-grained relatively near-source alluvial-fan deposits, and megabreccia deposits of long run-out landslides. Tephrochronology studies are used to 


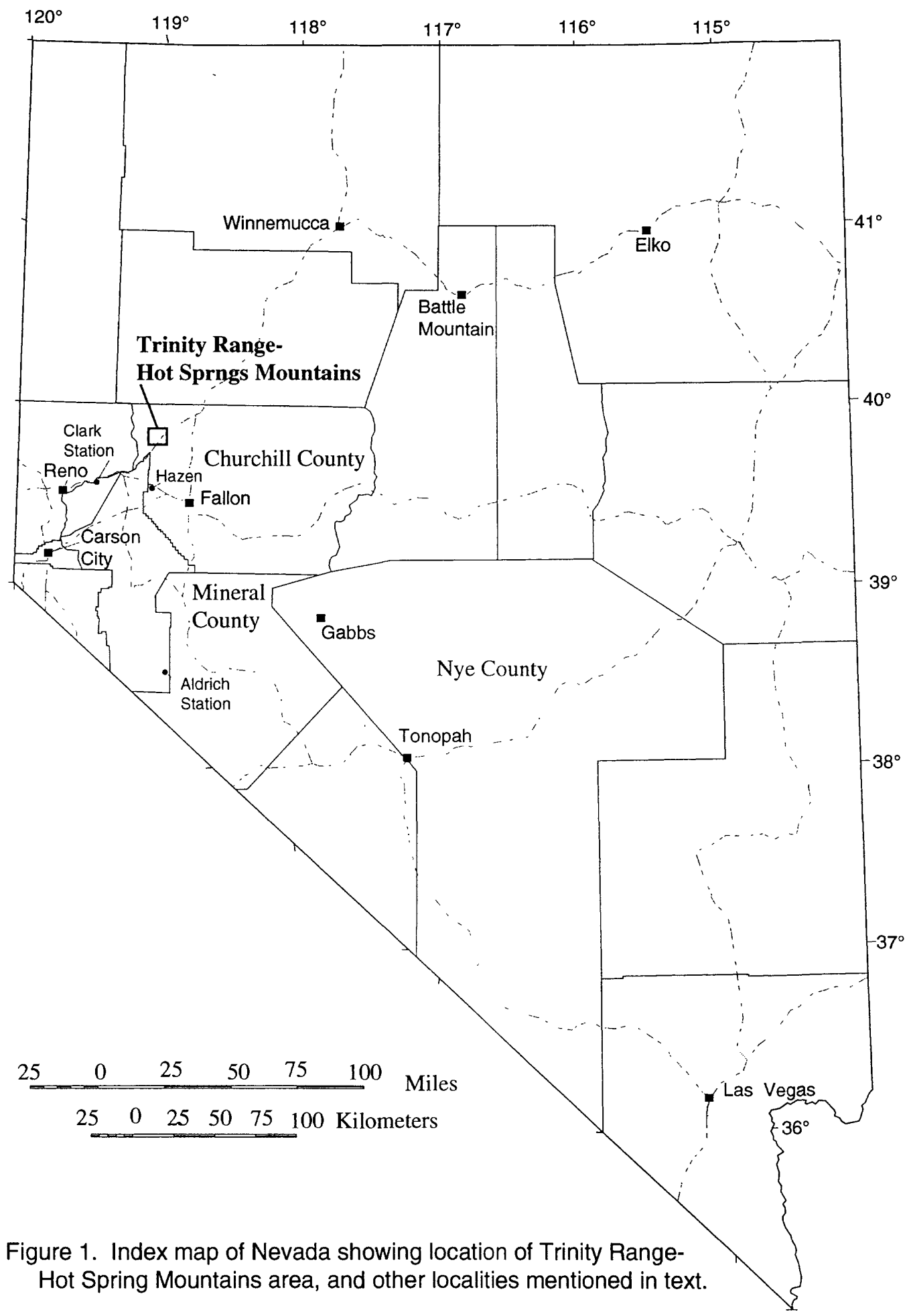


date (1) the time of deposition of the Truckee Formation and (2) the structural changes that produced these lithologic changes.

\section{STRATIGRAPHY}

The main part of the Tertiary rocks in the Trinity Range-Hot Springs Mountains area consists, in ascending order, of the Choropagus, Desert Peak, Truckee Formations of Miocene age, and gravels of Miocene and Pliocene? age (Fig. 3). The Chloropagus Formation varies in thickness from about 120 to $800 \mathrm{~m}$. It consists of amyduloidal or vesicular basalt, andesite breccia and agglomerate, and minor amounts of tuffaceous sandstone, shale, siliceous shale, and tuff. Isotopic ages range from 13.9 to $14.5 \mathrm{Ma}$ (Axelrod, 1956; Benoit and others, 1982). The Desert Peak Formation is divided into two members (Axelrod, 1956; Insert Fig. 1Benoit and others, 1982). The lower member, ranges in thickness from 0 to $260 \mathrm{~m}$ according to Axelrod (1956) and consists of basalt, basaltic tuff, and thick porcelaneous shale (Axelrod, 1956; Benoit and others, 1982). The upper member is 488 to $670 \mathrm{~m}$ thick according to Axelrod (1956) and is composed mainly of siliceous shale, opaline dolostone, and basaltic tuff (Axelrod, 1956; Benoit and others, 1982). Benoit and others (1982) indicate that the entire Desert Peak Formation is $274 \mathrm{~m}$ thick, considerably thinner than the thickness indicated by Axelrod (1956)

The Truckee Formation and overlying gravel are the main focus of this report and are described separately below.

\section{TRUCKEE FORMATION}

The Truckee Formation was divided by Axelrod (1956) into three members.

Lower member. The lower member of the Truckee Formation is, according to Axelrod (1956), $328 \mathrm{~m}$ thick and composed of alternating thin siliceous shale, basaltic tuff, tuffaceous sandstone, and diatomite. We did not study this member in detail, or appraise its stratigraphy as described by Axelrod (1956).

Middle member. The middle member is widespread in the Trinity Range and Desert Peak area, particular in the relatively low areas near Interstate Highway I-80 between the Trinity Range and Desert Peak area. The member contains the diatomite mines and prospects that are common in the area. It consists dominantly of soft, white laminated diatomite, locally with thin pumice or ash beds and thin sandstone beds. Axelrod (1956) indicates that the middle member is $450 \mathrm{~m}$ thick, although the unit is poorly exposed and is faulted, making estimates of thickness uncertain. We think that this member, as well as the lower member, could be thinner than indicated by Axelrod (1956).

Upper member. The upper member of the Truckee Formation is heterogeneous and contains claystone, siltstone, sandstone, conglomerate, gravel, and megabreccia. It is the main focus of this study. We mapped the upper member with two different nomenclatural systems, one for the area east of a fault along the west side of what we here informally call "Hill-4561" (Fig. 2) and the other for the area west of this fault. The stratigraphic succession differs somewhat from one side of the fault to the other, although some units are similar and individual tephra layers can be correlated across the fault on the basis of their similar chemical composition (see section "tephrochronology" below). We think that the unlike facies across the fault, as described below, is probably the result of left-lateral offset. 

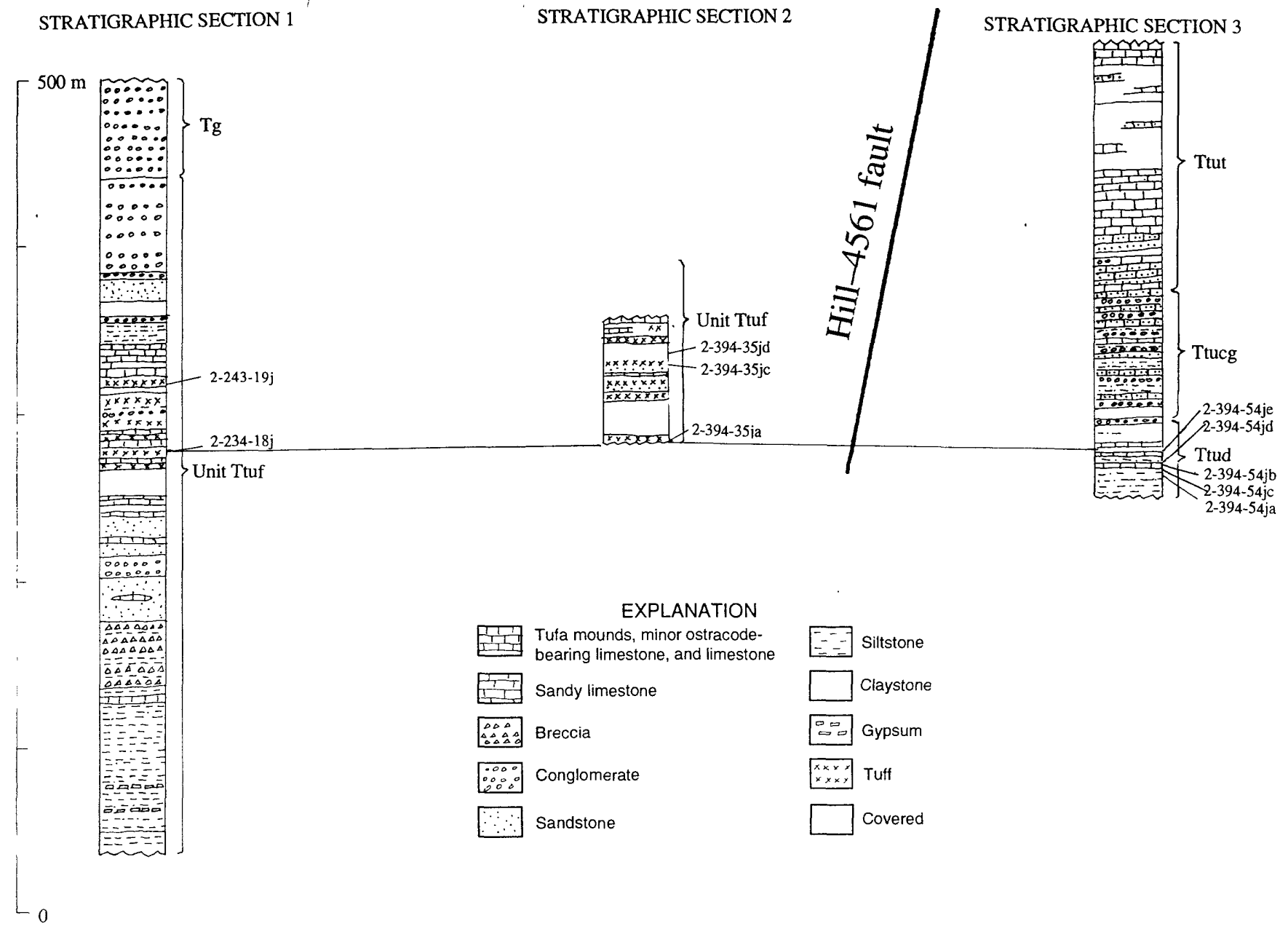

Figure 3. Stratigraphic colunns of upper member of Truckee Formation. Location of stratigraphic columns shown on figure 2. 


\section{Upper member of the Truckee Formation east of Hill-4561 fault}

East of the Hill-4561 fault, the upper member of the Truckee Formation is divided, in ascending order, into units Ttud, Ttucg, and Ttut.

Unit Ttud consists of diatomaceous siltstone and sparse ostracode-bearing limestone as well as tufa, vitric ash, tuffaceous sandstone, and volcanic-clast sandstone (Appendix, stratigraphic section 3). Unit Ttud has an incomplete thickness of $35.2 \mathrm{~m}$ in section 3 , and its complete thickness is probably over $100 \mathrm{~m}$.

Unit Ttucg consists of clastic limestone and ostracode-bearing limestone, conglomerate, and diatomaceous siltstone. The conglomerate contains clasts of basalt, rhylolite, dacite, hornfels, mostly of granule to pebble size but locally as large as cobble size. Unit Ttucg is $77.4 \mathrm{~m}$ thick in stratigraphic section 3 (Appendix).

Unit Ttut contains abundant tufa mounds (Fig. 4), some with thinolitic structures similar to those in tufa deposits at Pyramid Lake and Mono Lake (Shearman and others, 1989; Bischoff and others, 1993; Council and others, 1993; Shearman, 1998). The unit also has non-thinolitic tufa characterized by concentric or radiating structures. The tufa masses commonly are constructed around tree or plant material that has decayed leaving cylindrical holes marking the former positions of stems or logs. The impressions of the stems or logs can be seen on the sides of the holes (Fig. 5). In places, the former stems or logs are in growth positions, but in other places they are horizontal, perhaps indicating a position on a beach. Unit Ttut is $146 \mathrm{~m}$ thick in stratigraphic section 3 (Appendix), although the top of the unit is a fault at the stratigraphic section and some thickness of strata is missing.

\section{Upper member of the Truckee Formation west of Hill-4561 fault}

West of the Hill-4561 fault, the upper member of the Truckee Formation (Unit Ttuf) consists of relatively fine-grained strata (Ttuf) interstratified with major subunits of coarse conglomerate and volcanic breccia (Ttuc). The upper member west of the Hill-4561 fault also contains one, or possibly two, megabreccia deposits formed by long-runout landslides.

Unit Ttuf, excluding the coarser grained parts (unit Ttuc), consists of claystone, clayey siltstone, and minor gypsum in the lower part (units 1-6, stratigraphic section 1); sandstone (units 8 and 10); limestone, fine-grained tuff, and opalized tuff (unit 12); silicified tuff (unit 13); poorly exposed tuff, limy siltstone and conglomerate (unit 14); tufa (unit 15); limestone (unit 16); siltstone (unit 17); poorly exposed sandstone and tuffaceous siltstone (unit 19 and 20); and conglomerate and sandstone (unit 22). Unit 22 is coarser than the other subunits in the finer grained facies of Ttuf, and could be assigned to unit Ttuc, rather than the undivided part of Ttuf. We have not done that because unit 22 appears to contain sandstone whereas the underlying unit of Ttuc (unit 21) is entirely conglomerate, and overlying unit Tg is coarse conglomerate. Nevertheless, unit 22 represents a relatively coarse uppermost part of unit Ttuf, indicating a general coarsening upward succession in the upper member of the Truckee Formation transitional into the even coarser conglomerate of unit $\mathrm{Tg}$.

Unit Ttuc consists of several relatively coarse conglomerate and breccia layers interstratified with the relatively fine-grained sediments of the undivided part of unit Ttuf. The lowest part of unit Ttuc is subunit 7 (stratigraphic section 1) consists of volcanic breccia composed of clasts of andesite and dacite? mostly as large as 1 to $10 \mathrm{~cm}$, but some as large as $1 \mathrm{~m}$. The breccia within subunit 7 is interstratified with silty claystone. The next higher subunit of Ttuc is subunit 9 consisting of conglomerte and sandstone. The conglomerate consists of clasts of andesite, dacite, and sparse slate and hornfels, the lowest unit containing slate and hornfels clasts from presumably a Mesozoic source terrain. The next higher layer of Ttuc is subunit 18 composed of clasts of andesite and dacite, and sparse hornfels, slate, and tufa. Tufa clasts are locally as large as $1 \mathrm{~m}$. Unit 21 is the 

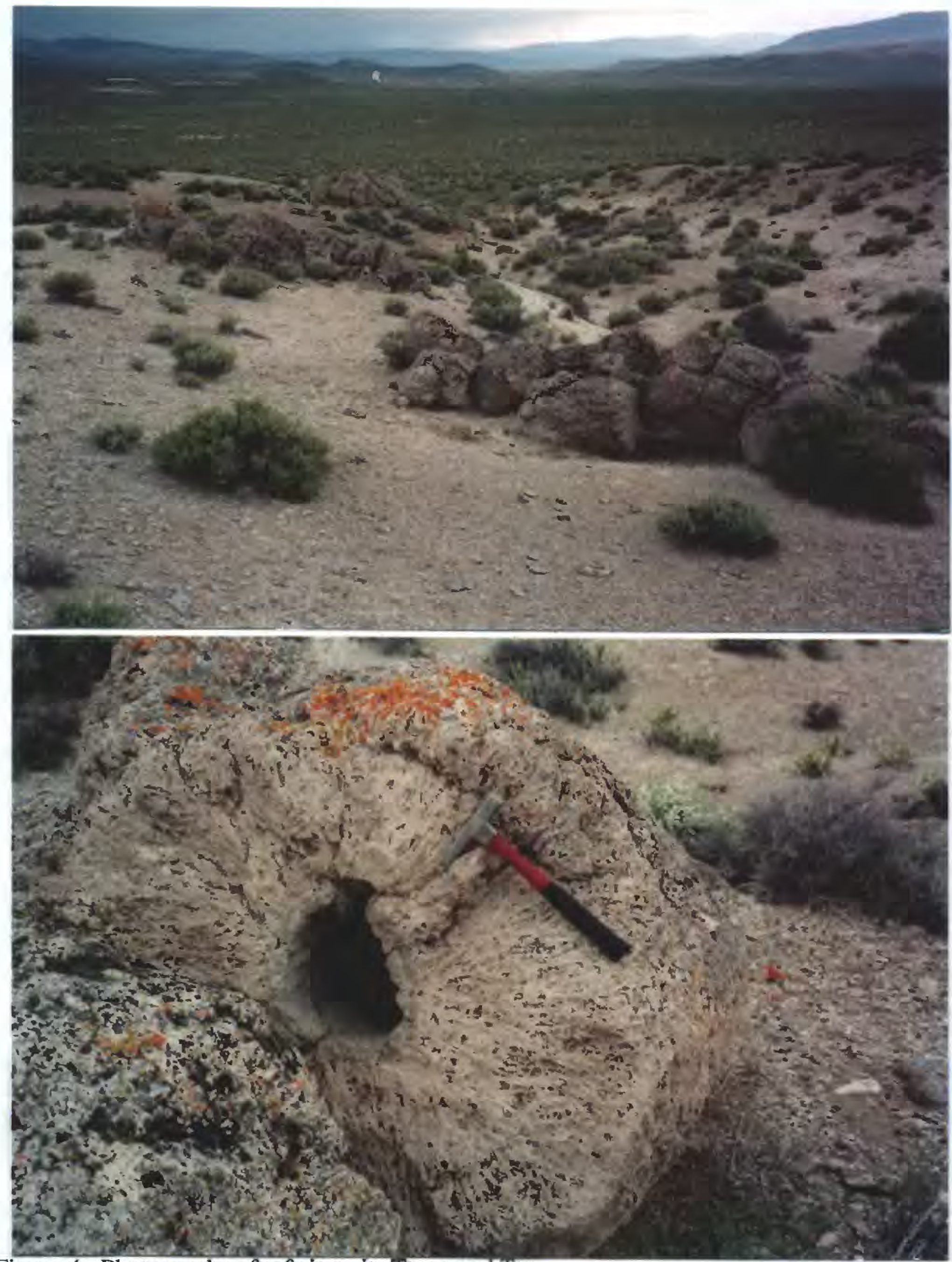

Figure 4. Photographs of tufa in units Ttucg an tru

Upper photograph shows broken tufa mounds. Tufa in foreground probably was a vertical column that has now collapsed. Small white area in the distance, slightly to the left of the upper center of the photograph, is stream from Brady's hot springs geothermal area. Lower phtograph shows tufa that has grown around a tree and has subsequently eroded away leaving a hollow tube. Note radial structure that is similar to tufa domes of Pleistocene Lake Lahontan in western Nevada (Shearman and others, 1989, fig. 3). 

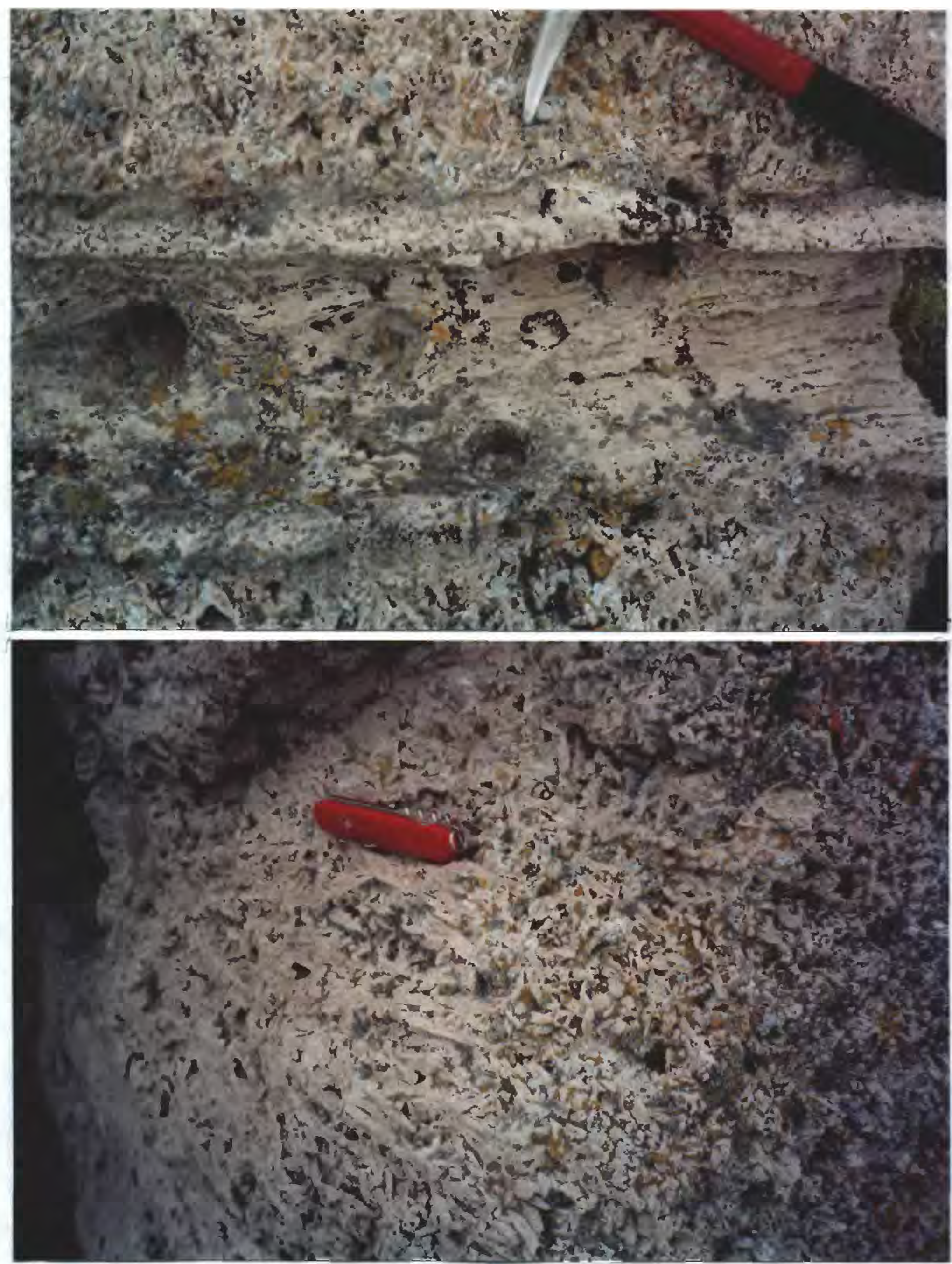

Figure 5. Photographs showing details of tufa mounds.

Upper photograph shows impression of tree. Note tree bark structures and knots. Structures similar to this can be observed on hollow tubes like that illustrated in the lower photograph of Figure 4. Tufa above and below impression of tree shows poorly developed thinolite.

Lower photograph shows well-developed thinolite. 
highest layer of Ttuc. It is composed of a thin conglomerate with clasts of dacite, andesite, basalt, slate, hornfels, and tufa. The subunits of coarser material (Ttuc) within unit Ttuf, are highly lenticular and some units of Ttuc pinch out along the outcrop. This irregularity is considered to indicate lenticular alluvial-fan deposits interfingering with finer grained lacustrine or fluvial deposits. We suspect that erosional channels are fairly common at the base and within the coarse conglomeratic deposits of Ttuc, but because of poor outcrops these structures can be noted in only a few places.

Unit Ttmg is a megabreccia of biotite dacite, glassy dacite, andesite, and vesicular basalt. Blocks are mostly from 1 to $3 \mathrm{~m}$ in size, although in some areas blocks of one rock type cover 30-to-60 $\mathrm{m}$ wide surface areas. The unit is generally poorly exposed, and rock textures are difficult to see. In places, the unit may be associated with volcanic breccia, some of which is finer grained than the megabreccia. The main outcrops of Ttmg are in the northeast part of section 19, T. 23 N., R. 27 E. Here Ttmg is present in two layers that may be two distinct depositional units or the same depositional unit that is repeated by faulting.

\section{CONGLOMERATE AND GRAVEL UNIT}

The conglomerate and gravel unit is widely exposed in the western part of the map area. It is composed of subangular to subrounded clasts of basalt, andesite? and rhyolite, as well as sparse hornfels, slate, metavolcanic rocks and tufa. We suspect that this conglomerate and gravel unit is composed of channel-filling and lenticular layers, but because of poor outcrops, this was not observed. In most places, clasts are 1 to $10 \mathrm{~cm}$ wide, but coarse conglomerate and gravel also are present. Interstratified with the conglomerate and gravel is at least one 5-to-10-m layer of sand (unit Tgs) composed of quartz, feldspar, and sparse clasts of granite. Unit Tgs was clearly derived from a granitic terrane.

\section{Tephrochronology}

Primary and reworked ash-fall tuff beds are common in the Truckee Formation. We collected 17 tuff samples from localities $1-10$ in the vicinity of the Hill-4561 fault (Table 1; fig. 2). Fifteen tuff samples are from the upper member and two are from the lower member of the formation. Four additional samples were collected by Brown (1986) from locality 11 (Fig. 2). Tuffs at this latter locality, termed "One Tip" by Brown (1986) are in the middle member of the formation. Glass shards from all the samples were analyzed for major and minor elements on the Cameca SX-50 electron microprobe at the University of Utah using the methods and instrumental conditions discussed by Perkins and others (1995). In addition, glass separates from the four tuffs at locality 11 were analyzed for trace and minor elements by X-rayflourescence (XRF) spectrometry (Brown, 1986). Results of the electron probe microanalyses are summarized in Table 2, and the results of the XRF analyses are given in Table 3.

The succession and age of the tuffs in the Truckee Formation were evaluated using the approach of Perkins and others (1998). The analyses of the tuffs of the Truckee Formation were compared with those in the extensive University of Utah tephra database. This database includes stratigraphic information, ages, and glass shard analyses of late Cenozoic vitric tuffs from throughout the western United States. These comparisons, in conjunction with stratigraphic observations on the relative position of the tuffs, establish the likely succession of tuffs in the Hill-4561 fault area (Fig. 6, 7). Correlation of nine of the tuffs in the Truckee Formation with fallout tuffs dated by Perkins and others (1998) establishes the age of the tuffs in the upper and middle members of the Truckee formation as 11.8 to $9.4 \mathrm{Ma}$ (Fig. 8), as described in detail below.

Tuffs in the Hill -4561 fault area are mostly gray vitric metaluminous tuffs (Gm tuffs of Perkins and others, 1998). In the terminology of Perkins and others (1998) these 
Table 1. Stratigraphic location and correlation of tephra samples. Stratigraphic sections 1, 2, and 3 are in Appendix. Names and dates of ash beds after Perkins and others

Unit Ttuf (1998)

Sample 2-443-19j, (map location 11), correlates with qd3-41, Opal Canyon 6 ash bed ( 9.5 Ma), Hazen, Nevada.

Sample 2-443-31j (map location 10), correlates with qdl-67, or qd4c at Hazen, Nevada

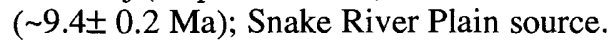

Sample 2-394-61j (map location 7), correlates with qe-6 ( 9.8 Ma), Hazen ash bed, Hazen, Nevada; Snake River Plain source.

Sample 2-443-18j (map location 1), basal $30 \mathrm{~cm}$ of unit 12, stratigraphic section 1 , correlates with qe-6 ( 9.8 Ma), Hazen ash bed, Hazen, Nevada; Snake River Plain source. Sample 2-394-35ja (map location 3), vitric tuff, lower $1 / 4$ of unit 1 , stratigraphic section 2. Probably correlatrive with qe-6 (9.8 $\pm 0.1 \mathrm{Ma})$, Hazen ash bed, Hazen, Nevada; Snake River Plain source.

Sample 2-394-35jc (map location 3), 1-2 cm-thick vitric ash bed, $16.5 \mathrm{~m}$ above base of unit 4, stratigraphic section 2. No specific correlation. General similarity to 10.5 to $8.5 \mathrm{Ma}$ ash beds in Snake River Plain.

Sample 2-394-35jd (map location 3), 20-cm-thick vitric ash bed. Collected about $45 \mathrm{~m}$ south of stratigraphic section 3 in a stratigraphic position that appears to be equivalent to a covered interval (unit 5) along line of section. Approximately in a position equivalent to $6 \mathrm{~m}$ above base of unit 5, stratigraphic section 2. No correlative tephra found. General similarity to 10.5 to 8.5 ash beds in Snake River Plain.

Sample 2-443-5j (map location 2), correlates with CPT XIII ash bed (Couger Point

Unit Ttut

Tuff unit XIII ash bed) (10.94 +/-0.03 Ma) Snake River Plain source.

Unit Ttud

Sample 2-394-41j (map location 5). No correlative tephra found.

Sample 2-394-54ja (map location number 6), 10-cm-thick vitric ash bed, base of ash bed is $4.6 \mathrm{~m}$ below top of unit 1, stratigraphic section 3. Probably correlates with qe-6 (9.8 Ma), Hazen ash bed, Hazen, Nevada; Snake River Plain source. Glass shards in samples 2-39454ja, 2-394-54jd, and 2-394-54je all appear compositionally identical to those of the Hazen ash bed on the basis of electron probe analyses. Elsewhere, the Hazen ash bed is a single bed, and why there are three Hazen-like ash beds here is not known. The possibility that the upper two tephra are reworked from the lower one seems unlikely because the tephra are fresh and undisturbed. Faulting that could duplicate tephra layers was not observed in the field. Further analyses are needed to establish which of these three beds is the most likely correlative of the Hazen ash bed.

Sample 2-394-54jc (map location number 6), 4-cm-thick coarse vitric ash bed, base of ash bed 2.9 $\mathrm{m}$ above base of unit 2, stratigraphic section 3. Dacite pumice lapilli ash. No correlative tephra known.

Sample 2-394-54jb (map location number 6), 7-cm-thick andesitic crystal tuff (plagioclase, clinopyroxene, and hornblende), near base of tuffaceous sandstone $9.8 \mathrm{~m}$ above base of unit 2 , stratigraphic section 3 . No correlative tephra known.

Sample 2-394-54jd (map location number 6), 3-cm-thick vitric ash bed, base of ash bed is $11.4 \mathrm{~m}$ above base of unit 2, stratigraphic section 3. Correlates with qe-6 (9.8 Ma), Hazen ash bed, Hazen, Nevada; Snake River Plain source.

Sample 2-394-54je (map location number 6), 11-cm-thick vitric ash bed, base of ash bed is $19.9 \mathrm{~m}$ above base of unit 2, stratigraphic section 3. Correlates with qe-6 (9.8 Ma), Hazen ash bed, Hazen, Nevada; Snake River Plain source.

Unit Ttm

Sample 2-394-49j (map location 9), correlates CPT XI ash bed, ( 11.3 Ma).Sample 2-395-46j (map location 8), Dacite pumice lapilli ash bed. No correlative tephra found.

Sample ot-4 (map location 12), One-Tip section of F.H. Brown, correlates with CPT IX ash bed ( 11.6 Ma), Snake River Plain source.

Sample ot-3 (map location 12), One Tip section of F.H.Brown, Browns Hill ash bed (11.7 Ma), Snake River Plain source. 
Sample ot-2 (map location 12), One Tip section of F.H. Brown, correlates with Rainier Mesa ash bed $(11.72+/-0.05 \mathrm{Ma})$. Source in southwest Nevada volcanic field.

Sample ot-1 (map location 12), One Tip section of F.H. Brown, correlates with Ibex Peak 8 ash bed ( 11.8 Ma), Snake River Plain source. 
Table 2. Electron probe microanalyses of glass shards - average composition.

[in weight percent]

\begin{tabular}{|c|c|c|c|c|c|c|c|c|c|c|c|c|c|c|c|c|}
\hline Samples & $n^{\prime}$ & $\mathrm{SiO}_{2}$ & $\mathrm{TiO} 2$ & $\mathrm{Al}_{2} \mathrm{O}_{3}$ & $\mathrm{Fe}_{2} \mathrm{O}_{3}^{2}$ & $\mathrm{MnO}$ & $\mathrm{MgO}$ & $\mathrm{CaO}$ & $\mathrm{BaO}$ & $\mathrm{Na}_{2} \mathrm{O}$ & $\mathrm{K}_{2} \mathrm{O}$ & $\mathrm{Cl}$ & $F$ & -0 & $\mathrm{H}_{2} \mathrm{O}^{3}$ & Sum \\
\hline 2-394-35ja & 20 & 73.2 & 0.32 & 11.7 & 2.22 & .037 & 0.12 & 0.79 & 0.07 & 1.5 & 5.7 & .027 & 0.25 & 0.11 & 5.2 & 101.0 \\
\hline 2-394-35jc & 20 & 73.2 & 0.30 & 11.5 & 2.58 & .038 & 0.09 & 0.83 & 0.08 & 1.9 & 5.7 & .027 & 0.26 & 0.12 & 4.3 & 100.7 \\
\hline 2-394-35jd & 20 & 73.3 & 0.27 & 11.5 & 2.53 & .044 & 0.08 & 0.74 & 0.08 & 1.9 & 5.7 & .026 & 0.27 & 0.12 & 4.9 & 101.2 \\
\hline $2-394-41 j$ & 20 & 73.6 & 0.35 & 11.8 & 2.12 & .030 & 0.15 & 0.79 & 0.06 & 2.2 & 5.8 & .030 & 0.24 & 0.11 & 4.4 & 101.5 \\
\hline $2-394-46 j$ & 17 & 71.3 & 0.12 & 14.5 & 1.21 & .107 & 0.41 & 1.68 & 0.10 & 1.7 & 2.4 & .095 & 0.12 & 0.07 & 6.6 & 100.3 \\
\hline $2-394-49 j$ & 20 & 73.4 & 0.21 & 11.5 & 2.10 & .029 & 0.05 & 0.62 & 0.03 & 1.8 & 5.8 & .043 & 0.19 & 0.09 & 4.8 & 100.5 \\
\hline $2-394-54 j a$ & 19 & 73.4 & 0.31 & 11.6 & 2.39 & .028 & 0.10 & 0.82 & 0.08 & 2.1 & 5.8 & .031 & 0.25 & 0.11 & 5.1 & 101.9 \\
\hline $2-394-54 j c$ & 20 & 69.4 & 0.37 & 14.4 & 1.93 & .089 & 0.49 & 1.61 & 0.04 & 3.1 & 3.9 & .239 & 0.21 & 0.14 & 5.7 & 101.3 \\
\hline 2-394-54jd & 20 & 73.1 & 0.32 & 11.6 & 2.26 & .036 & 0.12 & 0.79 & 0.08 & 2.1 & 5.8 & .029 & 0.26 & 0.12 & 4.9 & 101.3 \\
\hline 2-394-54je & 20 & 73.0 & 0.32 & 11.6 & 2.33 & .034 & 0.12 & 0.79 & 0.08 & 2.0 & 5.9 & .030 & 0.25 & 0.11 & 5.1 & 101.4 \\
\hline $2-394-61 j$ & 21 & 73.5 & 0.33 & 11.6 & 2.31 & .037 & 0.12 & 0.79 & 0.07 & 2.2 & 5.6 & .030 & 0.23 & 0.10 & 4.7 & 101.4 \\
\hline $2-443-5 j$ & 19 & 73.8 & 0.20 & 11.5 & 2.18 & .038 & 0.03 & 0.66 & 0.04 & 2.1 & 5.3 & .042 & 0.29 & 0.13 & 5.9 & 102.0 \\
\hline $2-443-10 j$ & 20 & 73.2 & 0.26 & 11.3 & 2.37 & .035 & 0.08 & 0.69 & 0.08 & 1.8 & 4.9 & .024 & 0.28 & 0.12 & 6.3 & 101.2 \\
\hline $2-443-18 j$ & 19 & 73.2 & 0.33 & 11.6 & 2.25 & .037 & 0.12 & 0.78 & 0.08 & 2.2 & 5.4 & .029 & 0.23 & 0.10 & 4.8 & 101.0 \\
\hline $2-443-19 j$ & 20 & 72.8 & 0.32 & 11.8 & 2.43 & .036 & 0.12 & 0.84 & 0.09 & 2.2 & 5.4 & .034 & 0.25 & 0.11 & 5.3 & 101.5 \\
\hline $2-443-31 j$ & 20 & 72.2 & 0.41 & 12.0 & 2.52 & .044 & 0.20 & 0.97 & 0.06 & 2.3 & 5.4 & .029 & 0.26 & 0.12 & 5.0 & 101.3 \\
\hline ot -1 & 20 & 72.2 & 0.30 & 11.3 & 1.99 & .021 & 0.11 & 0.71 & 0.10 & 1.4 & 5.4 & .019 & 0.09 & 0.04 & 6.6 & 100.2 \\
\hline ot -2 & 21 & 73.0 & 0.09 & 11.8 & 0.56 & .054 & 0.05 & 0.34 & 0.01 & 2.0 & 6.1 & .075 & 0.10 & 0.06 & 6.2 & 100.3 \\
\hline ot-3 & 23 & 72.4 & 0.15 & 11.7 & 0.91 & .046 & 0.13 & 0.59 & 0.12 & 2.0 & 5.4 & .154 & 0.01 & 0.04 & 7.2 & 100.8 \\
\hline ot -4 & 19 & 72.2 & 0.24 & 11.3 & 1.84 & .021 & 0.07 & 0.58 & 0.06 & 2.1 & 6.0 & .027 & 0.11 & 0.05 & 5.4 & 99.9 \\
\hline
\end{tabular}

Table 3. XRF analyses of glass shards separates 1 .

Oxides in weight percent; other elements in parts per million]

\begin{tabular}{|c|c|c|c|c|c|c|c|c|c|c|c|c|c|c|c|c|}
\hline Sample & $\mathrm{Fe}_{2} \mathrm{O}_{3}{ }^{2}$ & $\mathrm{CaO}$ & $\mathrm{K}_{2} \mathrm{O}$ & $\mathrm{Ba}$ & $\mathrm{Mn}$ & $\mathrm{Nb}$ & $\mathrm{Rb}$ & $\mathrm{Sr}$ & $\mathrm{Ti}$ & $Y$ & $\mathrm{Zn}$ & $\mathrm{Zr}$ & La & $\mathrm{Nd}$ & Th & $\mathrm{Ce}$ \\
\hline ot-1 & 1.91 & 0.72 & 4.24 & 949 & 215 & 42 & 195 & 46 & 1820 & 61 & 35 & 427 & 80 & 60 & 28 & 146 \\
\hline ot-2 & 0.54 & 0.34 & 5.54 & 1 & 432 & 29 & 213 & 7 & 618 & 44 & 28 & 72 & 22 & 27 & 22 & 53 \\
\hline ot-3 & 0.92 & 0.63 & 4.89 & 1129 & 364 & 8 & 108 & 85 & 1001 & 12 & 26 & 114 & 25 & 25 & 12 & 53 \\
\hline ot -4 & 1.68 & 0.53 & 5.40 & 555 & 178 & 40 & 203 & 27 & 1361 & 62 & 35 & 346 & 80 & 55 & 28 & 148 \\
\hline
\end{tabular}




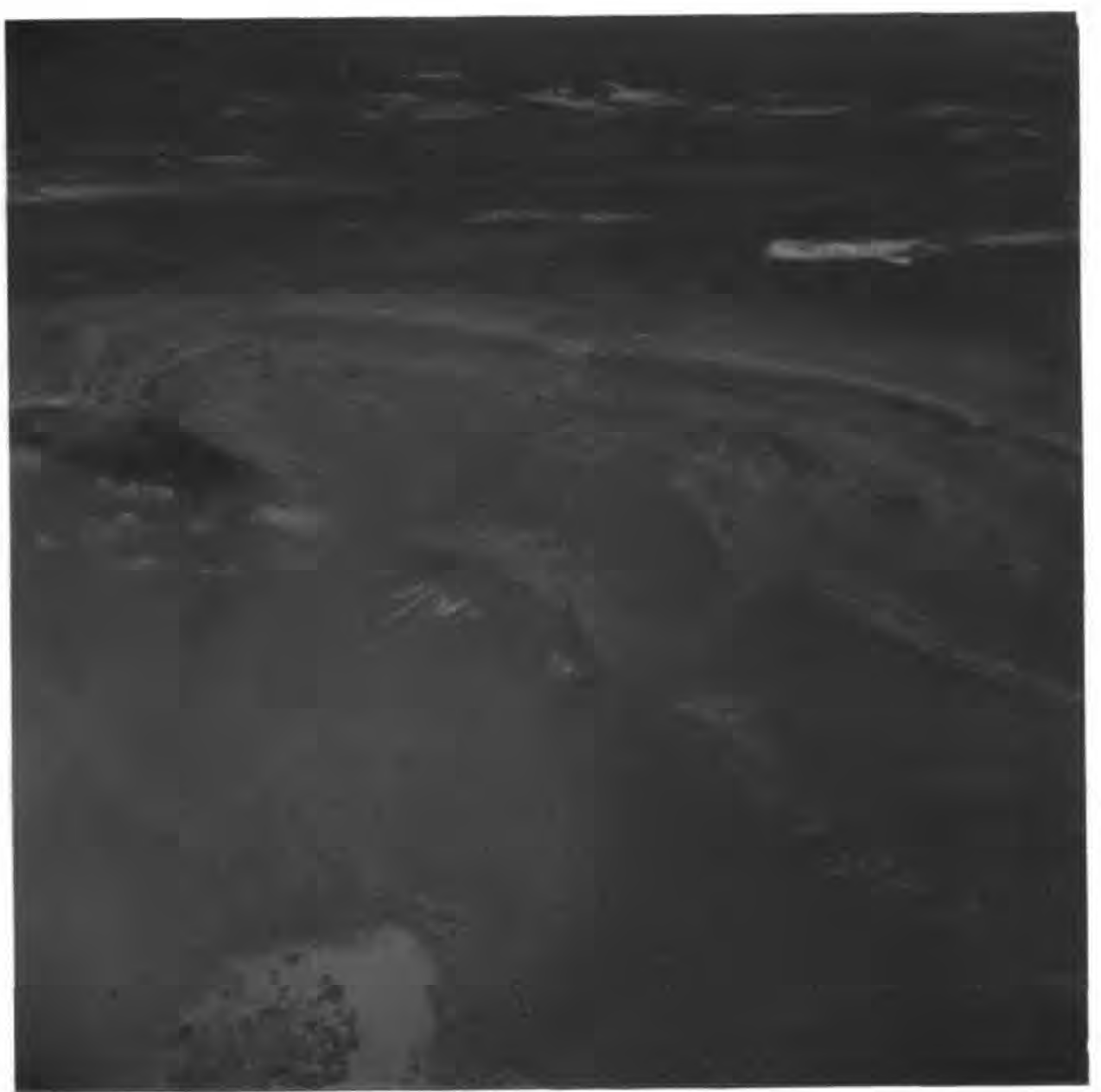

Figure 6. Photograph of Hill-4561 showing drag fold and left-lateral fault. Dark colored outcrop on left-hand side of photograph are breccias and intrusions of basalt. 


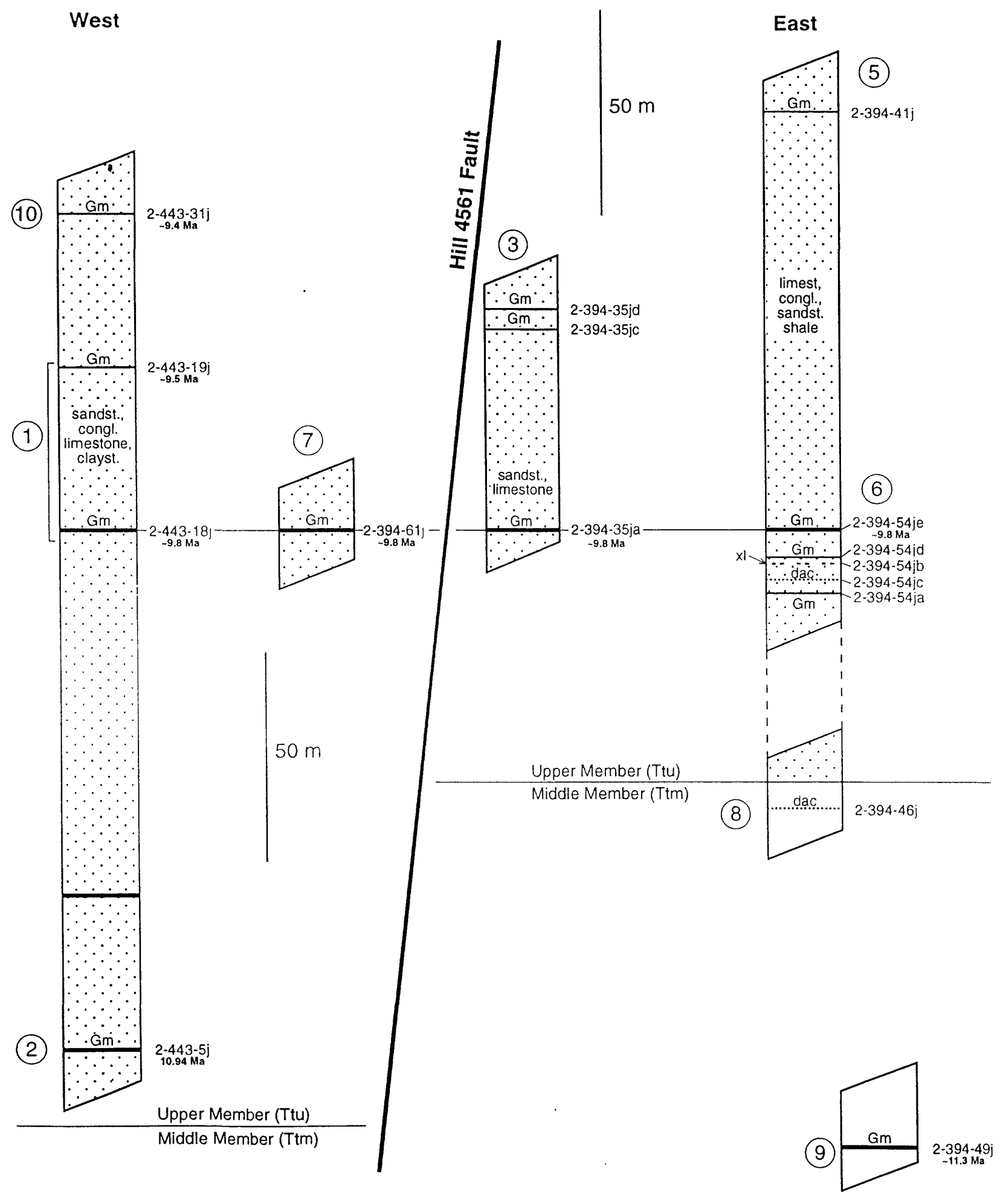

Figure 7. Diagram showing correlation of ash-fall tuffs in Hill-4561 area. Gray metaluminous rhyolite vitric tuffs (Gm type tuffs) from sources in the Snake River volcanic province are the most common type of tuff in this area, but two dacite pumice lapilli tuffs (dac) and an andesite crytal tuff (xl) also are present. Circled numbers are sample localities as shown in figure 2. See Fig. 8 for the names of regional correlation of dated tuffs. 
are SRP-type (Snake River Plains type), and are from sources in the Snake River Plain volcanic province. The glass shard compositional range of the lowest SRP-type tuffs in the area $(2-443-5 \mathrm{j}$ and $2-349-49 \mathrm{j}$ indicate a general age range of $10.5-8.5 \mathrm{Ma}$. One tuff,represented by sample 2-443-18j and correlative 2-394-61j, 2-394-35jc, 2-394-je, and, probably, 2-394-35ja), is identified on both sides of the Hill-4561 fault (Fig. 7). This tuff (same as the Hazen ash bed of Perkins and others, 1998) shows that strata of the upper member of the Truckee Formation are roughly coeval across the fault. Tuffs at locality 11 (One Tip) include both SRP-type gray vitric tuffs and white biotitic metaluminous rhyolite tuffs (Wm tuffs of Perkins and others, 1998). In Miocene basins of the northern Basin and Range, Wm tuffs are mainly from sources in the northwestern Nevada volcanic field and are most abundant in strata older than $11 \mathrm{Ma}$ (Perkins and others, 1998).

Thus, the general character of the tuffs indicates that the upper member of the Truckee Formation is in the range 10.5-8.5 Ma and the middle member is about $11 \mathrm{Ma}$ or older. Correlation of individual ash-flow tuffs gives more specific ages for the upper and lower members (Fig. 8). Five dated tuffs in the upper member range in age from about 11.8 Ma (Logan Ranch ash bed) to about 11.3 Ma (CPT XI ash bed = Cougar Point Tuff unit XI ash bed). Five dated tuffs in the upper member range in age from $10.94 \mathrm{Ma}$ (Cougar Point Tuff unit XIII ash bed) to about 9.4 Ma (unnamed ash bed). Since electron proble analyses of glass shards do not always uniquely identify ash beds (Perkins and others, 1998), correlation of tuffs in the upper member should be regarded as preliminary. However, since the succession of tuffs in the member matches successions of tuffs in other sections in the region (Fig. 8), it is likely that most or all of these preliminary correlations will prove correct when tested by more definitive XRF analyses of trace elements.

\section{ENVIRONMENTS OF DEPOSITION}

The middle and upper members of the Truckee Formation constitute a complex of lacustrine, low-energy fluvial, alluvial-fan, and landslide deposits.

The middle member is composed mainly of evenly laminated lacustrine diatomite. The absence of coarse layers is indicative of quiet-water deposition in an area of little topographic relief.

The upper member of the Truckee Formation, in contrast to the lower member, contains abundant coarse fluvial deposits which increase in amount and coarseness of the deposits upward. East of the Hill-4561 fault, unit Ttud contains abundant diatomaceous siltstone and represents a lacustrine deposit apparently gradational into the diatomites of the middle member. Unit Ttucg contains abundant conglomerate and near-shore tufa deposits indicative of either streams entering a lake or of coarse beach and associated near-shore tufa deposits. Unit Ttut is somewhat finer grained than unit Ttucg, but represents a similar near-shore environment with common tufa mounds.

West of the Hill-4561 fault, the upper member contains fine-grained lacustrine deposits in its lower part, and an increasing amount of coarse-grained alluvial-fan deposits upward. Some alluvial-fan layers are lenticular, and interfinger and pinch out into the finer grained part of the upper member. Megabreccia deposits (Ttumb) in the upper member are considered to represent long-runout landslide deposits.

\section{ONSET OF BASIN AND RANGE FAULTING}

The middle and upper members of the Truckee Formation and overlying conglomerate and gravel show an upward change from quiet-water lacustrine deposition, with no coarse detrital material, to coarse alluvial-fan deposits derived from nearby areas of high topographic relief. This change is accompanied by long-runout landslide deposits and also by an upward change in clast composition from mainly Tertiary volcanic clasts in the lower part of the upper member, to conglomerate that contains Mesozoic slate and hornfels 


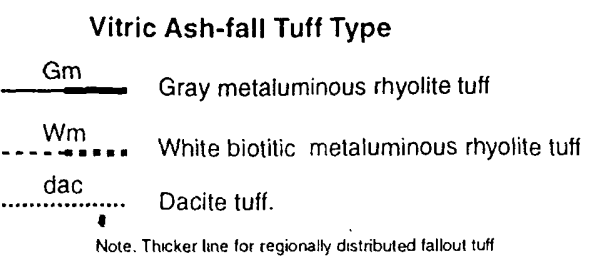

Hazen, NV

Aldrich

Stn., NV

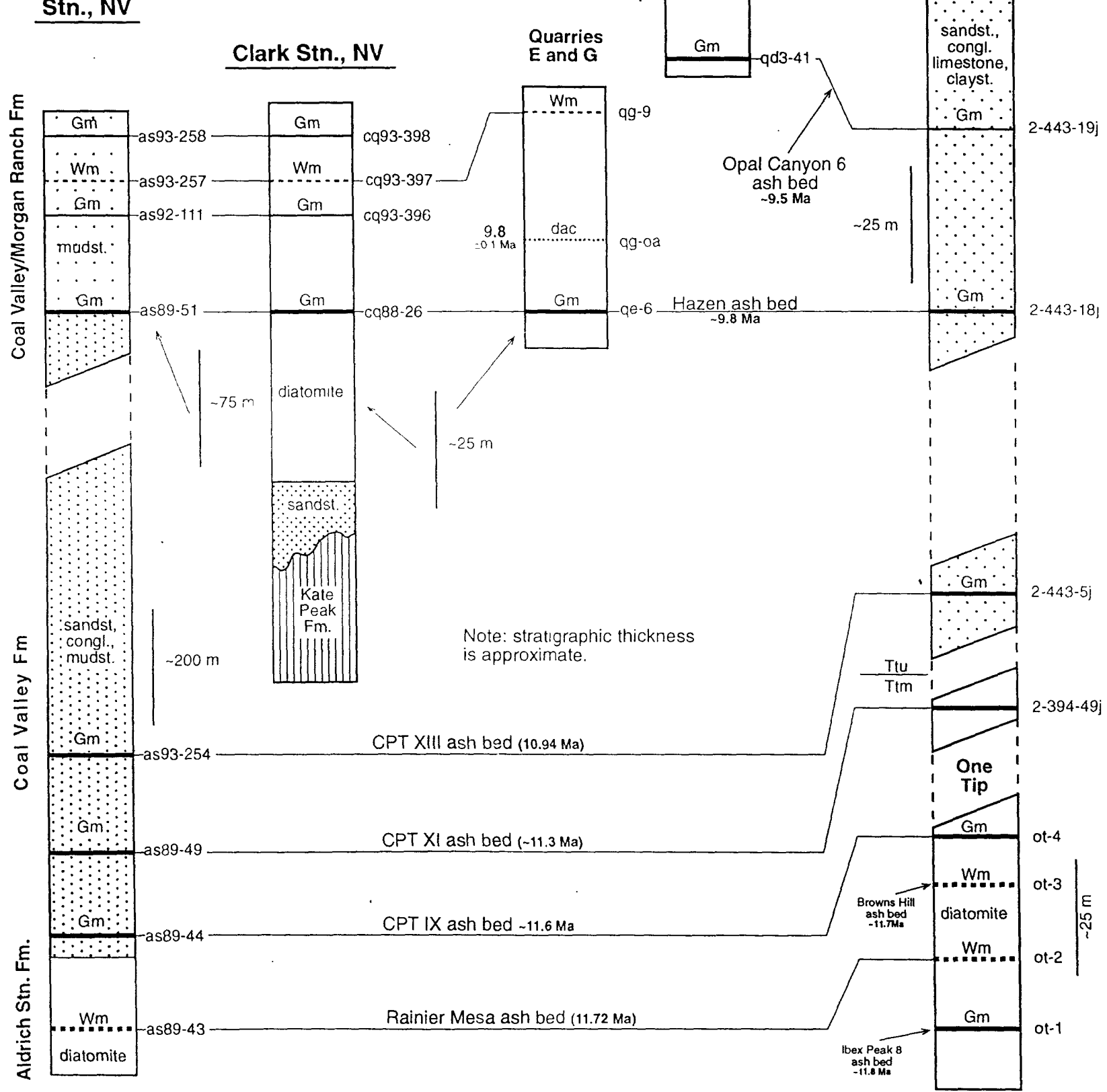

Figure 8. Diagram showing correlation and dates of vitric tuffs in Truckee Formation in the Trinity Range-Hot Springs Mountains area with vitric tuffs in correlative strata in three other areas of west-central Nevada. Names and dates of ash beds after Perkins and others (1998) Dates preceded by " $"$ are interpolation estimates; other dates are isotopic ages.
Truckee Fm.

Trinity RangeHot Springs Mitns. Area

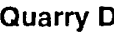

Hill 4561 
clasts in the middle part of the middle member, to local sand layers that have a Mesozoic granitic provenance in the conglomerate and gravel unit. These factors suggest a progressive increase in topographic relief in source areas during deposition of the upper member of the Truckee Formation. The change in clast composition suggests progressive unroofing of provenance areas that initially contained only Tertiary volcanic rocks, but that with continued erosion exposed first Mesozoic metamorphic rocks and then Mesozoic granitc rocks. A similar upward coarsening and change in clasts composition has previously been described in Miocene sedimentary rocks in the Coal Valley area (Golia and Stewart, 1984), $120 \mathrm{~km}$ south of the Trinity Range-Hot Springs Mountains area.

The upward coarsening and changes in clast composition indicate a significant change in the structural setting of the Trinity Range-Hot Springs Mountains area during deposition of the middle and upper members of the Truckee Formation. This change is considered to mark the onset of basin and range faulting in the region that produced the present-day block-faulted mountains of the Basin and Range province. This change is younger than the middle member of the Truckee Formation (11.6-11.8 Ma) and coeval with deposition of the upper member of the Truckee Formation (10.1 to 9.4 Ma)

\section{LEFT-LATERAL HILL-4561 FAULT}

A major fault, the Hill-4561 fault, extends north-south through the central part of the map area. This fault marks a significant change in the stratigraphic succession from sections on the east side of the fault that contain relatively abundant tufa deposits to sections on the west side of the fault that contain lesser amounts of tufa, and more tuff (Fig. 4). Correlation of sections across the fault is assured by the presence the same tephra layer in all three stratigraphic sections (Fig. 4 and Table 1). The change of facies across the fault is suggestive of lateral faulting that has juxtaposed somewhat unlike successions that were originally more widely separated. Such lateral faulting also is suggested by the conspicuous drag fold (Fig. 7) near Hill-4561 on the west side of the Hill-4561 fault. The drag fold indicates that the Hill-4561 fault is left lateral.

\section{REFERENCES CITED}

Axelrod, D.L., Mio-Pliocene floras from west-central Nevada: University Publications in Geological Sciences, v. 33, 321 p.

Benoit, W.R., Hiner, J.E., and Forest, R.T., 1982, Discovery and geology of the Desert Peak geothermal field: A case history: Nevada Bureau of Mines and Geology, Bulletin 97, $81 \mathrm{p}$.

Bischoff, J.., Stine, S., Rosenbauer, R.J., Fitzpatrick, J.A., and Stafford, J.W., Jr., 1993, Ikaite precipitation by mixing shoreline springs and lake water, Mono Lake, California, USA: Geochimica el Cosmochimica Acta, v. 57, p. 3855-3865.

Brown, F.N., 1986, Report on correlation of quarries in the Hazen area by chemical anaysis of tephra layers: Final Technical Report of National Science Foundation Contract 431-2681-A, 23 p.

Council, T.C., and Bennett, P.C., 1993, Geochemistry of ikaite formation at Mono Lake, California: Implications for the origin of tufa mounds: Geology, v. 21, p. 971974.

Garside, L.J., and Schilling, J.H., 1979, Termal waters of Nevada: Nevada Bureau of Mines and Geology, Bulletin 91, 163 p.

Golia, R.T., and Stewart, J.H., 1984, Depositional environments and paleogeography of the upper Miocene Wassuk Group, west-central Nevada: Sedimentary Geology, Special Publication 38, p. $159-180$.

King, Clarence, 1878, Systematic geology: U.S. Exploration 40th Parallel, v. 1 
Krebs, W.N., Bradbury, J.P., and Therriot, Edward, 1987, Neogene and Quaternary lacustrine diatom biochronology, western USA: Paleo-Lacustrine theme issue, Society of Economic Paleontologists and Mineralogists, p. 505-513.

Perkins, M.E., Brown, F.N., Nash, W.P., McIntosh, W., and Williams, S.K., 1998, Sequence, age, and source of silicic fallout tuffs in middle to late Miocene basins of the northern Basin and Range province: Geological Society of America Bulletin, v. 110 , p. 344-360.

Perkins, M.E., Nash, W.P., Brown, F.H., and Fleck, R.J., 1995, Fallout tuffs of the Trapper Creek, Idaho-A record of Miocene explosive volcanism in the Snake River Plain volcanic province: Geological Society of America Bulletin, v. 107, p. 1484-1506.

Shearman, D.J.,, Mcgugan, A., Stein, C., and A.J. Smith, 1989, Ikaite, $\mathrm{CaCO}_{3} .6 \mathrm{H}_{2} \mathrm{O}$, precursor of the thinolites in the Quaternary tufas and tufa mounds of the Lahontan and Mono Lake Basins, western United States: Geological Society of America, v. 101, p. 913-917.

Shearman, Douglas, 1998, The Mono Lakes tufas and ikaite columns of Ikka Fjord, Greenland: Geoscience 98, Keele University, v. 8, no. 1, p. 5 and 8.

Stewart, J.H., 1992, Paleogeography and tectonic setting of Miocene continental strata in the northern part of the Walker Lane Belt, in Craig, S.D., ed., Structure, tectonics, and mineralization of the Walker Lane, Walker Lane Symposium, Proceedings Volume: Reno, Nevada, Geological Society of Nevada, p. 1-16.

Stewart, J.H., Sarna-Wojcicki, Andrei, Meyer, C.E., Starratt, S.W., and Wan, Elmira, 1999a, Stratigraphy, tephrochronology, and structural setting of Miocene sedimentary rocks in the Middlegate area, west-central Nevada: U.S. Geological Survey Open File Report 99-350, 17 p.

Stewart, J.H., Sarna-Wojcicki, A.M., Meyer, C.A., and Wan, Elmira 1999b, Stratigraphy, tephrochronology, and structural setting of Miocene sedimentary rocks in the Cobble Cuesta area, west-central Nevada: U.S. Geological Survey Open File Report 99-352, 17 p.

Willden, Ronald, and Speed, R.C., 1974, Geology and mineral deposits of Churchill County, Nevada: Nevada Bureau of Mines and Geology, Bulletin 83, 95 p. 


\section{APPENDIX}

\section{STRATIGRAPHIC SECTION 1}

Thickness

Top of section

meters

Conglomerate and gravel unit ( $\mathrm{Tg}$ ) (incomplete)

23. Conglomerate, composed of clasts of basalt, andesite?, rhyolite, and sparse hornfels, slate, and tufa. Clasts are mostly 1 to $10 \mathrm{~cm}$, some as large as $30 \mathrm{~cm}$, in diameter.

Total of incomplete conglomerate and gravel unit $(\mathrm{Tg})$

Truckee Formation (incomplete):

Upper member (incomplete):

Unit Ttuf (incomplete)

22. Conglomerate and sandstone (?). Conglomerate, mostly composed of subangular to subrounded broken clasts of tufa, 10 percent Tertiary volcanic clasts and pre-Tertiary hornfels and slate (some epidote-bearing clasts). Sandstone (?) may be interlayered with conglomerate, but consists only of loose material.

21. Conglomerate, appears to be part of section but poorly exposed. Composed of subrounded to subangular clasts of dacite, andesite, basalt, slate, hornfels, and tufa.

20. Poorly exposed. Possibly mostly fine- to medium-grained sandstone; some tuffaceous siltstone.

19. Covered.

18. Conglomerate, appears to be part of section but only float exposed Composed of subrounded clasts of dacite and andesite, sparse hornfels, and slate. Sparse tufa clasts. Clasts mostly 1 to $5 \mathrm{~cm}$ in diameter, some as large as $10 \mathrm{~cm}$. Major change in lithology at base of unit 18. Unit 18 and higher are mostly conglomerate and include clasts of tufa as large as $1 \mathrm{~m}$ locally...

17. Siltstone, white, one thin layer of limy siltstone in middle of unit........ 15.2

16. Limestone, very pale orange, contains ostracodes, evenly laminated to thin bedded, Tufa bounds (as much a $1 \mathrm{~m}$ high) form top surface of unit. Lower third of unit contains common fine platy splitting tuff.

15. Tufa, yellow gray to very pale orange, forms rounded domes in lower, and top, $1 \mathrm{~m}$ of unit. Amount of tufa varies along outcrop. Common ostracode-limestone between tufa mounds. Minor white, fine-grained tuff.

14. Poorly exposed. Lower part contains float of fine-grained platy splitting tuff. A yellow-gray limestone is present from 6.4 to $6.6 \mathrm{~m}$ above base of unit. A limy siltstone layer is present about $3 / 4$ of way up in unit. Locally contains 3-m-thick layer of conglomerate composed of subangular, 1 to $6 \mathrm{~cm}$, clasts of vesicular and nonvesicular basalt, sparse dark-gray hornfels, and sparse flow-banded rhyolite.

13. Silicified tuff, light gray, forms minor ledge

12. Limestone, fine-grained tuff, and opalized tuff. Poorly exposed. Limestone, yellow gray, mostly in lower half of unit where it forms 20 to $30 \mathrm{~cm}$ thick layers. Basal $30 \mathrm{~cm}$ of unit is limestone with small gastropods. Tuff and opalized tuff, white, fine grained, platy splitting, local root casts

11. Covered ........................................................ 16.8 
10. Sandstone, yellow gray, fine to medium grained, grains of feldspar volcanic rocks, and ash? A few interstratified thin layers of ostracode limestone.

9. Conglomerate and sandstone, all loose material. Conglomerate consists of subangular to somewhat rounded clasts of andesite

(Unit 9 continued) and dacite and sparse greenish-gray slate and hornfels. Sandstone, light brown, fine to coarse grained.

8. Sandstone, light brown to pale yellow brown, fine to coarse grained composed of feldspar, quartz?, mafic minerals, and grains of volcanic rocks. A few 1 to $10 \mathrm{~cm}$ thick layers of pale-yellowbrown limestone with ostracodes and gastropods locally.

7. Volcanic breccia (all loose material) and interstratified silty claystone. Relative amount of rock types difficult to determine because of poor exposures. Volcanic breccia composed of subangular to angular clasts of at least two types of rocks (1) 70 percent brown andesite with 20 percent phenocrysts of plagioclase and biotite and (2) 30 percent pink dacite? with 20 percent phenocrysts of plagioclase and biotite. Most clasts are 1 to $10 \mathrm{~cm}$ in diameter, some are as large as $1 \mathrm{~m}$ in diameter. Probably lahar or debris flow

6. Claystone, pale yellowish brown, somewhat silty....

5. Limestone, very pale orange, fine grained, poorly indurated, porous. $\quad 3.4$

4. Claystone to clayey siltstone, very pale orange and grayish orange, and thin layers of white fine-grained tuff. Gypsum locally in float. Upper $10 \mathrm{~m}$ mostly covered. To south is $2-\mathrm{m}$-thick volcanic breccia that pinches out south of line of section.

3. Gypsum and claystone, forms white layer. Gypsum is in 1 to $2 \mathrm{~cm}$ thick layers that appear to be beds, rather than veins.

2. Claystone to clayey siltstone, pale orange to moderate brown, abundant float of gypsum..................................... 25.0

1. Claystone, pale orange....................................... 13.7

Total of unit Ttuf (incomplete) ........................................464.8

Total of upper member (incomplete) of Truckee Formation..................... 464.8 Base of section

Top of section

\section{STRATIGRAPHIC SECTION 2}

Truckee Formation (incomplete):

Upper member, incomplete):

Unit Ttuf (incomplete)

8. Tufa, domal mounds 0.3 to $1.8 \mathrm{~m}$ high, concentric internal

Thickness lamination

Meters

7. Poorly exposed, probably mostly very pale orange limestone, locally opalized. One layer of limestone contains ostrocodes. Possibly some tuff.

6. Tuff, partly opalized, yellow gray, fine to medium grained ash, quartz feldspar, and lithics, very thin laminae. Covered

5.

4. Tuff, limy sandstone, and octrocode-bearing limestone. Tuff, white
to very light gray, composed of fine to coarse grained ash, quartz, feldspar, and volcanic lithic fragments; some layers are all fine-grained tuff, others are coarse-grained tuff; laminated to thin bedded, probably all reworked tuff. Limy sandstone, very pale orange to moderate brown, composed of quartz, feldspar, lithic 
fragments, and coarse-grained ash cemented by calcite, grades to sandy limestone. Limestone, very pale orange, abundant ostracodes, locally gastropods are present. Amount of limy material increases upward in section. Lowest limestone in unit is $30 \mathrm{~cm}$ layer $5 \mathrm{~m}$ above base of unit.

3. Tuff, white to very light gray, minor medium-gray and yellow orange, fine grained, laminated to very thin bedded. Minor coarse-grained tuff containing 1-to-2-mm-size ash and volcanic lithics. Some thin beds grade upward from coarse-grained to fine-grained ash. Minor scours and load casts. Unit completely exposed in small ledge.....

2. Covered

1. Tuff, white to very light gray, fine-grained ash, some vitric ash, mostly nonvitric ash, poorly exposed.

Total of Unit Ttuf (incomplete) of upper member of Truckee Formation $7 \frac{. \cdots \cdots}{75.6}$ Base of section

Top of section

\section{STRATIGRAPHIC SECTION 3}

Truckee Formation (incomplete)

Upper member (incomplete)

Unit Ttut

Thickness

Meters

12. Tufa mounds, yellow gray, poorly preserved thinolite

13.4

11. Very poorly exposed, appears to be mostly detrital limestone and ostracode-bearing limestone, yellow gray....

10. Covered. Float mostly of detrital limestone and ostracode-bearing limestone.

9. Ostracode-bearing limestone, yellow-gray, sparse to abundant ostracodes in fine detrital matrix. Thin to very thin bedded. From 8.5 to $9.1 \mathrm{~m}$ above base of unit is tufa growing around molds of logs 10 to $20 \mathrm{~cm}$ in diameter.

8. Tufa mound, detrital and ostrocode-bearing limestone, and sparse tuffaceous sandstone and conglomerate. Tufa mounds, yellow gray, mostly thinolitic, some have radial structure that are not thinolitic, common molds of trees that weather as holes in the tufa. Detrital and ostrocode-bearing limestone forms most of the unit that is not tufa. Tuffaceous sandstone is present in unit from 21.3 to $25.3 \mathrm{~m}$ and 30.8 to $31.4 \mathrm{~m}$ above base of unit. This tuffaceous sandstone is fine to medium grained and composed of ash, quartz, feldspar, and dark gray volcanic rock fragments. From 20.7 to $21.3 \mathrm{~m}$ above base of unit is conglomerate composed of rounded coarse sand to small pebbles of limestone (tufa?)

Total of unit Ttut. mixed with coarse sand and small pebbles of mafic volcanic rock... $\underline{37.8}$ Unit Ttucg

7. Poorly exposed. Detrital and ostracode-bearing limestone (40 percent), conglomerate, (30 percent), and diatomaceous siltstone (30 percent). Detrital and ostrocode-bearing limestone, yellow gray, grades from detrital rock composed of irregular fine-grained limestone grains to limestone composed almost entirely of ostracodes; laminated to thin bedded. Conglomerate, only seen as float, but in definite layers. Clasts of basalt, rhyolite, dacite, hornfels; mostly granule to pebble size, some clasts as large as $8 \mathrm{~cm}$. Diatomaceous siltstone, similar to that in unit 1 ; all float. Isolated tufa mound at 
36.8 to $37.5 \mathrm{~m}$ above base of unit.................................. 70.1

6. Covered......................................................... 4.3

5. Conglomerate, all float, but definite layer. Composed of subangular to subround granules to pebbles as large as $7 \mathrm{~cm}$ of reddish-brown aphanitic vesicular basalt, dacite(?), aphanitic flow-banded rhyolite, siliceous rock (rhyolite?), and black hornfels......................... 3.0

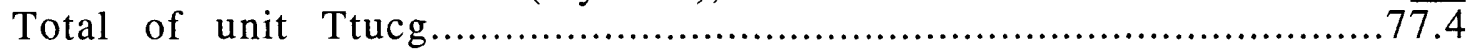
Unit Ttud

4. Mostly covered, common float of yellow gray, platy, diatomaceous siltstone. Exposed thin bed of ostracode-limestone at $11 \mathrm{~m}$ above base of unit.................................................... 11.9

3. Tufa, yellow gray to yellow brown, radiating structures from central cavity, forms round domal masses; discontinuous along outcrop.

2. Diatomaceous siltstone, similar to unit 1 . All float. Sparse very thin beds of ostracode-bearing limestone, vitric ash, tuffaceous sandstone, and volcanic-clast sandstone, and one layer of limestone composed of fine to medium grains of limestone and shelly? material.

1. Diatomaceous siltstone, yellow gray, platy spitting, all float, but appears to be essentially in place...................................... $\frac{11+}{35.2}$

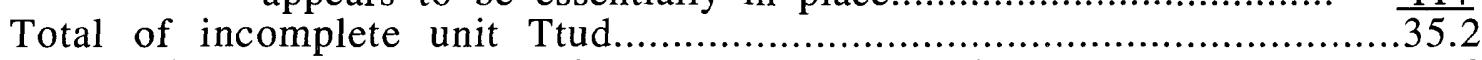

Total of incomplete upper member of Truckee Formation............................ 207.8 Base of section 